\title{
Intraoperative Irrigation With Ceftriaxone In Neurosurgical Patients
}

\author{
A Adeolu, A Malomo, T Shokunbi
}

\section{Citation}

A Adeolu, A Malomo, T Shokunbi. Intraoperative Irrigation With Ceftriaxone In Neurosurgical Patients. The Internet Journal of Neurosurgery. 2004 Volume 2 Number 2.

DOI: $\underline{10.5580 / 1 \mathrm{c} 08}$

\begin{abstract}
This prospective study was carried out to determine the safety of ceftriaxone [CTRX] applied topically to nervous tissue. During an industrial action in 1999 , surgical procedures were performed in hospital settings where neurosurgical procedures had not been previously performed. The risk of infection and use of antimicrobial irrigation were explained to the patients and their relatives. There were fourteen procedures in ten patients with male: female ratio of 2:3. The age range was three months to sixty five years. One patient had postoperative seizure which was controlled with anticonvulsant. There were no neurological toxicity or dysfunction observed during a follow up period of one year. It appears that CTRX is safe for intraoperative irrigation in neurosurgical patients. A larger study sample will be needed to validate these results.
\end{abstract}

\section{INTRODUCTION}

Postoperative infection in neurosurgical patients is an important cause of morbidity and mortality. Various ways have been used to decrease the incidence of postoperative infections including the adoption of aseptic technique and perioperative systemic antibiotics ${ }_{1}{ }_{2},{ }_{3}, 4$. Malis in 1979 reported $0 \%$ incidence of postoperative infections following combination of systemic and topical antibiotic irrigation . $_{5}$ Since then various studies have been done to evaluate the efficacy of intraoperative topical antimicrobial irrigation in neurosurgery $6,7,8,9,10$. Haines and Goodman ${ }_{6}$ and Geraghty and Feely ${ }_{7}$ reported incidence of less than one percent in their studies; they used same antimicrobial agents as in Malis study and achieved incidence of $0.9 \%$ and $0.5 \%$ respectively. The feasibility of using topical antimicrobial agents on nervous tissue demonstrated by these various studies suggests that the method can be used especially in unusual circumstances with high possibility of postoperative infection. Irrigation fluid with antimicrobials is also advocated where intracranial implants are inserted for example in ventriculoperitoneal shunts. The present study evaluates the safety of CTRX as a topical antimicrobial prophylaxis in neurosurgical procedures. CTRX was used because of its known efficacy in surgical prophylaxis. CTRX is a broad spectrum antibiotic with good central nervous system (CNS) activity. Furthermore, CTRX is free from important adverse effects such as neurotoxicity, nephrotoxicity and ototoxicity which may occur with gentamicin and streptomycin used in previous studies. A previous study had also suggested low inhibition of rat brain membrane ATPases by CTRX. [Unpublished data]. This animal study suggested that CTRX may be safe when applied directly to nervous tissue.

\section{PATIENTS AND METHODS}

The patients enrolled for the study were those who had neurosurgical procedures during an industrial crisis which made us to operate these patients in equipped but unaccustomed operating suites. There were fourteen procedures in ten patients [two patients were operated twice]. The risk of infections as well as the likely gains and possible complications of antimicrobial irrigation were explained to patients and their relations and consent obtained for their use .Ceftriaxone solution $(250 \mathrm{ug} / \mathrm{ml})$ was chosen because a previous in-vitro study of its effect on brain membrane ATPases [unpublished data] suggests that it is safe for brain irrigation. We monitored the patients` recovery from anaesthesia including vital signs, difficulties with reversal of muscle relaxants, undue prolongation of drowsiness. We also observed for any unusual neurological deterioration including seizures and vomiting. Close monitoring was for 72 hours. The anesthetists and nursing staff who did the acute phase monitoring and recording did 
not, at that time, know if a particular patient received CTRX or not.

\section{RESULTS}

The table below summarizes the results. There were five females and four males. The age range was from three months to sixty five years. Half of the patients were infants. Only one patient had shunt tract infection.

This patient had obstructed umbilical hernia which was operated in the same admission. He re-presented about two months after with distal shunt infection.

There were no complications or difficulties associated with the patients recovery from anesthesia. We also did not observe any unexpected neurological complications in any of the patients both in the period of closed monitoring and follow up.

\section{Figure 1}

Table 1: Summary of ten patients who had intraoperative irrigation with ceftriaxone

\begin{tabular}{|c|c|c|c|c|c|}
\hline & AGE & SEX & DIAGNOSIS & $\begin{array}{l}\text { SURGICAL } \\
\text { PROCEDURE }\end{array}$ & COMPLICATIONS \\
\hline 1 & 6 Montาs & M & $\begin{array}{l}\text { Congenital } \\
\text { Hydrocephalus }\end{array}$ & Right Frontal V-P Shurt & - \\
\hline 2 & 7 Monts & M & $\begin{array}{l}\text { Congenital } \\
\text { Hydrocephalus }\end{array}$ & Right Frontal V-P Shurt & - \\
\hline $3^{*}$ & $\begin{array}{l}15 \\
\text { Months }\end{array}$ & M & $\begin{array}{l}\text { Postmeningitic } \\
\text { Hydrocephalus }\end{array}$ & Right Frontal V-P Shurt & Shunt Infection \\
\hline $4^{*}$ & 8 Montrs & $\mathrm{F}$ & $\begin{array}{l}\text { Hydranencephaly } \\
\text { Myeiomeningocele }\end{array}$ & $\begin{array}{l}\text { Right Frontal V-P Shurt } \\
\text { Repar } \alpha \\
\text { Myelomeningocele } \\
\text { [Shunt Reviewed Twice } \\
\text { For Malfunctioning] }\end{array}$ & $\begin{array}{l}- \text { Shunt } \\
\text { Malfunction } \\
\text {-Left Focal } \\
\text { Seizures }\end{array}$ \\
\hline 5 & 19 Years & $\mathrm{F}$ & $\begin{array}{l}\text { Postmeningitic } \\
\text { Hydrocephalus }\end{array}$ & Right Frontal V-P Shurt & $=$ \\
\hline $6^{+}$ & 3 Montrs & $\mathrm{F}$ & $\begin{array}{l}\text { Lumbosacral } \\
\text { Myelomeningocele }\end{array}$ & $\begin{array}{l}\text { Repair of } \\
\text { Myelomeningocele } \\
\text { [Reoperated Twice] }\end{array}$ & Csf Fistula \\
\hline$T^{*}$ & 8 Montrs & $\mathrm{F}$ & $\begin{array}{l}\text { Bilateral Subdural } \\
\text { Ettusion And Brain } \\
\text { Maldevelopment with } \\
\text { Cerebral Atrophy }\end{array}$ & $\begin{array}{l}\text { Billateral Frontoparietal } \\
\text { Burr Holes }\end{array}$ & - \\
\hline 8 & 65 Years & $\mathrm{F}$ & $\begin{array}{l}\text { Spinal Cord } \\
\text { Compression } \\
\text { Syndrome }\end{array}$ & $\begin{array}{l}\text { D7,8 } \\
\text { Laminectorny.Right } \\
\text { Transversectomy And } \\
\text { Biopsy of D7 Body }\end{array}$ & - \\
\hline 9 & 40 Years & M & Empty Sella Syncrome & $\begin{array}{l}\text { Rigth Pterional } \\
\text { Craniotomy }\end{array}$ & - \\
\hline 10 & 43 Years & M & Pituitary Adenoma & $\begin{array}{l}\text { Rigth Pterional } \\
\text { Craniotomy And Gross } \\
\text { Total Tumor Excision }\end{array}$ & Hypopituitrism \\
\hline
\end{tabular}

OPERATIONS PERFORMED IN THE SAME HOSPITAL

\section{DISCUSSION}

Antimicrobial irrigation has been used safely in neurosurgical procedures ${ }_{5}, 6,7,8,9,{ }_{10}$. Agents like gentamicin and streptomycin seem to have been well established in this $\operatorname{regard}_{5},{ }_{6}, 7,8,9,{ }_{10}$. Their systemic use, however, is associated with nephrotoxicity (both) and ototoxicity (streptomycin) which CTRX is free from. The present study has shown that CTRX could be safe in human nervous tissue if applied topically at concentration within recommended serum level.
None of our patients had unusual complications that could be linked directly to the CTRX irrigation. Only one patient, who initially had right frontal ventriculoperitoneal shunt for hydranencephaly, had left focal seizures. This was controlled with phenobarbitone.

Apart from the patient who had distal shunt tract infection, which was perhaps related to an abdominal surgical intervention, no other patients had infection. This suggests that the regime could be effective in preventing postoperative infections. However, the patients also had systemic antimicrobial as perioperative prophylaxis: CTRX in all the patients as well as metronidazole in those who had repair of myelomeningocoele. CTRX has been suggested to have good cerebrospinal fluid penetration following parenteral administration ${ }_{11}$. Its use in irrigation fluid where indicated, in addition to its intravenous use, will prevent polypharmacy as well as the toxic effects of the more established aminoglycosides. Its satisfactory outlook in this series under extenuating circumstances will facilitate a bigger study and wider application for example in treating ventriculitis by susceptible organisms.

\section{CONCLUSION}

It appears that intraoperative irrigation of the brain with CTRX during neurosurgical procedures is safe. A controlled study with a larger sample will be required to validate these results.

\section{CORRESPONDENCE TO}

Dr AA Adeolu Department of Surgery College of health Sciences Obafemi Awolowo University, Ile-Ife, Nigeria Email: adeoluaa@yahoo.com Phone number: 234

8056164492

\section{References}

1. Djindjian M., Lepresle E., and Homs J.B.: Antibiotic prophylaxis during prolonged clean neurosurgery. J.Neurosurgery. 1990; 73:383-386

2. Blomstedt G.C., Kytta J.: Results of randomized trial of vancomycin prophylaxis in craniotomy. J.Neurosurgery. 1988; 69:216-220

3. Quartey G.R.C., Polyzoidis K.: Intraoperative antibiotic prophylaxis in neurosurgery: A clinical study. Neurosurgery. 1981; 8: 669-671.

4. Ajar F., Levin A.B., Duff T.A.: Effects of methicillin on cerebrospinal fluid shunt infections in children.

Neurosurgery. 1981; 9: 6-8

5. Malis L.I.: Prevention of neurosurgical infections by intraoperative antibiotics. Neurosurgery. 1979; 5:339-343

6. Haines S.J., Goodman M.L.: Antibiotic prophylaxis of postoperative neurosurgical wound infection.

J.Neurosurgery. 1982; 56: 103-105

7. Geraghty J., Feely M.: Antibiotic prophylaxis in neurosurgery; a randomized controlled trial. J.Neurosurgery. 
1984; 60:724-726.

8. Rekate H.L., Ruch T., Nulsen F.E.: Diphtheroid infections of cerebrospinal fluid shunts. The changing pattern of shunt infection in Cleveland. J.Neurosurgery.1980; 52: 553-556.

9. Maurice-Williams R.S., Pollock J.: Topical antibiotics in neurosurgery: a re-evaluation of Malis technique. British journal of Neurosurgery. 1999; 13: 312-315.

10. Yamamoto M., Jimbo M., Ide M., Tanaka N., Umebera
Y., Hagiwara S.: Perioperative antimicrobial prophylaxis in neurosurgery; clinical trial of systemic flomoxef administration saline containing gentimicin for irrigation. Neurologia Medico-Chirurgica. 1996; 36: 370-376.

11. Hattori T., Kobayashi H., Uno T.: Study on the penetration of ceftriaxone into cerebrospinal fluid. Japanese Journal of Antibiotics. 1996; 49: 813-817. 


\section{Author Information}

Augustine A. Adeolu

Department of Surgery, University College Hospital

\section{Adefolarin O. Malomo}

Department of Surgery, University College Hospital

\section{Temitayo M. Shokunbi}

Department of Surgery, University College Hospital 